Indonesian Journal of Physics and Nuclear Applications

Volume 1, Number 3, October 2016, p. 166-173

ISSN 2549-046X, (C) FSM UKSW Publication

\title{
Biological Shielding Design of In Vitro Test Facility Boron Neutron Capture Therapy (BNCT) at Radial Piercing Beam Port of Kartini Research Reactor Using MCNPX
}

\author{
Widarto', Buyung Edi Prabowo \\ ${ }^{1}$ Researcher of Center for Science and Accelerator Technology - National Nuclear Energy \\ Agency, J1. Babarsari No.21, Po Box 6101 ykbb, Yogyakarta 55281, Indonesia \\ ${ }^{2}$ Graduated of Physics Departement, Faculty of Mathematics and Science, Yogyakarta State \\ University, J1. Colombo No.1, Yogyakarta 55281, Indonesia
}

Received: 15 September 2015, Revised: 30 February 2016, Accepted: 26 August 2016

\begin{abstract}
This research aimed to determine material specification of radiation biological shielding design of neutron and gamma output on radial piercing beamport of Kartini Research Reactor using MCNPX code, as safety radiation protection purpose of in vitro / in vivo irradiation test facility. Refference input data using parameters of neutron and gamma as result simmulation researcher before as follows $\Phi_{\mathrm{th}}$ is $5.00 \times 10^{8} \mathrm{n} . \mathrm{cm}^{-2} \mathrm{~s}^{-1}, \Phi_{\text {epi }}$ is $1.23 \times 10^{8} \mathrm{n} . \mathrm{cm}^{-2} \mathrm{~s}^{-1}, \Phi_{\text {fast }}$ is 1.35 x $10^{9} \mathrm{n} \cdot \mathrm{cm}^{-2} \mathrm{~s}^{-1}, \check{\mathrm{D}}_{\gamma}$ is $2.49 \times 10^{-3} \mathrm{~Sv}_{\mathrm{s}}{ }^{-1}, \check{\mathrm{D}}_{\mathrm{n}}$ is $3.63 \times 10^{-1} \mathrm{~Sv}^{-1} \mathrm{~s}^{\text {th }}$. [ Dwi W.]Optimation result of simulation using MCNPX to determine specification material for radiation protection safety are parafin block with thickness $75 \mathrm{~cm}$ for neutron shielding and covered by material lead $(\mathrm{Pb})$ with thickness $15 \mathrm{~cm}$ for gamma shieding. By this optimation for the both thickness materials, determination for neutron and gamma dose rate are as follow, $\check{D}_{\mathrm{n}}=1,1 \mathrm{x}$ Sv.s $\mathrm{s}^{-1}$ and with $\check{\mathrm{D}}_{\gamma}=1,1$ $\mathrm{x} 10^{-09} \mathrm{~Sv} \cdot \mathrm{s}^{-1}$. Those radiation dose rate of neutron and gamma parameters are still under requirement of safety dose standard that is $2.78 \times 10^{-9} \mathrm{~Sv} \cdot \mathrm{s}^{-1}$ as regulation of Regulatory Body BAPETEN. [Perka BAPETEN No. 4 Tahun 2014]. It can be concluded that by the Biological Shielding Design of In Vitro Test Facility Boron Neutron Capture Therapy (BNCT)at Radial Piercing Beam Port of Kartini Research Reactor Using MCNPX can operated safely.
\end{abstract}

Keywords : BNCT, MCNPX, radial piercing beam port, biological shielding, neutron flux, radiation dose rate.

\section{INTRODUCTION}

Cancer is a disease that belongs to a group of non-communicable diseases (NonCommunicable Diseases or NCD). NCD is the largest cause of death in the world. Based on data from the World Health Organization (WHO), which was published in the World Health Statistics 2012, of the 57 million deaths in general in 2008 there were approximately 36 million deaths $(63 \%)$ due to non-disease outbreaks. Cancer ranks second cause of death after heart disease, which is about $21 \%$ of total non-communicable diseases, with an increase in mortality ranging from 7.6 million to 13 million per him. More than two-thirds of all cases of deaths caused by cancer occur in countries with low and middle incomes, including lung cancer, breast, colorectal and liver cancer. The majority of these cases end in death. In Indonesia there are approximately 165 deaths for every 100,000 populations due to cancer (WHO, 2012: 34).

According to data from Cancer Registration System in Indonesia (Sistem Registrasi Kanker, Srikandi) in 2005-2007 showed that cancer for children (0-17 years) amounted to 9 per 100.000 children. Cases of cancer in children is $4.7 \%$ of cancers in all ages. The death rate from cancer has reached $50-60 \%$ because of people commonly come late or are already in an advanced stage (Kemenkes RI, 2013a: 182). Data from Riskesdas 2013 by the Ministry of Health in 2013 that the prevalence of cancer was 1.4 per mil (Kemenkes RI, 2013b: ix). Cancer prevalence is highest in Yogyakarta (4.1\%o), followed by Central Java (2.1\%o), Bali (2 \%), Bengkulu and DKI Jakarta (1.9\%) (Kemenkes RI, 2014: 6.34)

Basically there are several standard methods of cancer therapy, such methods include: 
surgery, chemotherapy, and radiotherapy. Each of these therapeutic methods have limitations and drawbacks that may cause side effects in treating cancer, resulting in handling cancer does not only involve the methods of treatment. Combination drug therapies aim to suppress the side effects and increase the effectiveness of therapy in order to obtain maximum results. One part of the radiotherapy with the potential to be developed is the Boron Neutron Capture Therapy (BNCT)

BNCT method utilizes non-radioactive nuclide ${ }^{10} \mathrm{~B}$ to capture neutrons through this reaction ${ }^{10} \mathrm{~B}(\mathrm{n}, \alpha){ }^{7} \mathrm{Li}$. Results of this reaction has the characteristics Linear Energy Transfer (LET) high (for $\alpha$ particles approximately close to 150 $\mathrm{keV}_{\mu \mathrm{m}} \mathrm{-}^{-1}$ and for ${ }^{7} \mathrm{Li}$ approach $175 \mathrm{keV} \mathrm{m}^{-1}$ ). Coverage of these particles is approximately 4.5 $\mu \mathrm{m}$ to $10 \mu \mathrm{m}$, so that the energy is deposited is limited to a single cell (cell diameter of $18 \pm 2$ $\mu \mathrm{m}$ ) (Sauerwein, 2009: 8).

To support the BNCT facility, it is needed neutron source with certain criteria. BNCT neutron source at the facility can be obtained from the nuclear reactor or Compact Neutron Generator (CNG). In Indonesia there are three nuclear reactors for research purposes which is operated by the National Nuclear Energy Agency (BATAN), Multipurpose Reactor G.A. Siwabessy in Serpong, TRIGA 2000 Reactor Bandung, TRIGA MARK-II (Kartini Research Reactor, KRR) in Yogyakarta (Nina Fauziah, 2013:2). Of the three reactors, reactors that have been used for facility BNCT research is Kartini Research Reactor (KRR).

Radial piercing beam port of Kartini Research Reactor (KRR) is radiation channel that mounted to penetrate the shield of the reactor (reactor tank). The number of channels in KRR is 4 pieces. The fourth channel is used to provide neutron beam and gamma radiation. Three channels are connected in radial and the other channel in tangentially. Two radial channels are mounted to penetrate shields reactor until outside the reactor core is called radial beam port. While the channel which through until the reactor core is called radial piercing beam port (BATAN, 2013). The following radiation beam line drawings presented in Figure 1.

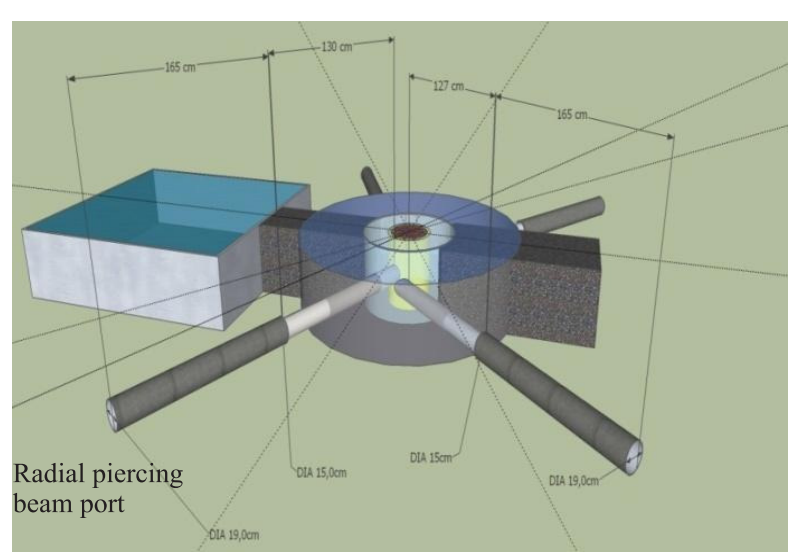

Figure 1.Radiation channel (beam port) at Kartini Research Reactor (KRR) (Indry, 2015: 16)

Radiation shields are used to reduce the intensity of the radiation which radiate from the radiation source. Radiation in the environment must be in accordance with the requirements set by the Nuclear Energy Regulatory Agency (BAPETEN). Dose Limit Value (NBD) stipulated in Perka BAPETEN No. 4/2013 on Protection and Radiation Safety in Nuclear Power Utilization, recommending that the effective dose for radiation workers by an average of $20 \mathrm{mSv}$ (twenty milisievert) per year (BAPETEN, 2013: 11). If the specified BAPETEN NBD at $20 \mathrm{mSv} /$ year or $10 \mu \mathrm{Sv} / \mathrm{h}$ (1 year equivalent to 2000 hours of work) are converted into units of the flux is $280 \mathrm{n} . \mathrm{cm}^{-2} \mathrm{~s}^{-1}$ for energy epithermal (BATAN, 2014: 22).

The research on the design of radiation shields on the radial piercing beam port KRR has been done by Bambang (2014). The design uses a simulator MCNP5 continuing research by Ilma (2013). This radiation shield design 
using barite concrete and paraffin material as a major component (Bambang, 2014: 38), while the radiation shields available in PSTA BATAN only paraffin. Research conducted at Bambang (2014) dimensions of the facility is not in accordance with the test facilities available at the PSTA-BATAN.

This research following on Dwi (2014) research, that have results of thermal, epithermal and fast neutron flux are $3.65 \times 10^{7} \mathrm{n} . \mathrm{cm}^{-2} \mathrm{~s}^{-1}$; $1.20 \times 10^{9} \mathrm{n} . \mathrm{cm}^{-2} \mathrm{~s}^{-1}$ and $1.89 \times 10^{9} \mathrm{n} . \mathrm{cm}^{-2} \mathrm{~s}^{-1}$ with gamma dose and neutron dose are $4.61 \times 10^{-3}$ Sv.s ${ }^{-1}$ and $3.74 \times 10^{-1}$ Sv.s ${ }^{-1}$ (Dwi Wahyuningsih, 2014: 53). In addition to the simulator MCNP5, input of the data is not capable of running well on MCNPX. This study complements previous research that simulated the design of the irradiation facility for the purposes of in vitro testing also functions as a radiation shield so that the radiation output of the radial beam port KRR meet safety standards BAPETEN using MCNPX.m

\section{RESEARCH METHODS}

\section{Time and Place of Research}

This study was conducted starting in July 2015 till September 2015 and the result is biological shielding design for in vitro BNCT facility at the radial piercing beam port KRR. The experiment was conducted at the Center for Accelerator Science and Technology, National Nuclear Energy Agency (PSTA-BATAN) is located at Jl. Babarsari Post Office Box 6101 ykbb Yogyakarta.

\section{Tools and Analysis Program}

a. Hardware: One unit of portable computer TOSHIBA $^{\circledR}$ Satellite C640D series, an unit Printer FX DocuPrint P215 b.

b. Software: Monte Carlo N-Particle eXtended ${ }^{\mathrm{TM}}$ (MCNPX), Visual Editor (Vised), Notepad, Command Promt,
Microsoft Office Excel $^{\odot}$ 2007, Microsof Office Word $^{\circledR} 2007$.

c. Material data and dimensional geometry in vitro irradiation facility and shielding KRR:

i. In vitro irradiation facilities $3 \times 2$ with dimensions of $12.8 \times 2.5 \times 8.5 \mathrm{~cm}$ of plastic material with a number of holes 6 pieces and each diameter hole is $3.8 \mathrm{~cm}$.

ii. In vitro irradiation facilities $6 \times 4$ with dimensions of $12.8 \times 2.5 \times 8.5 \mathrm{~cm}$ of plastic material with a number of holes 24 pieces and each diameter hole is 1.55 $\mathrm{cm}$.

iii. Paraffin block dimensions of $60 \times 30 \times$ $15 \mathrm{~cm}$.

iv. $\mathrm{Pb}$ sheet dimensions $50 \times 50 \times 0.5 \mathrm{~cm}$.

v. Results MCNP of radial piercing beam port by Dwi Wahyuningsih research (2014).
a). $\Phi_{\text {th }}=3.65 \times 10^{7} \mathrm{n} \cdot \mathrm{cm}^{-2} \cdot \mathrm{s}^{-1}$
b). $\Phi_{\text {epi }}=1.20 \times 10^{9} \mathrm{n} \cdot \mathrm{cm}^{-2} \cdot \mathrm{s}^{-1}$
c). $\Phi_{\text {fast }}=1.89 \times 10^{9} \mathrm{n} \cdot \mathrm{cm}^{-2} \cdot \mathrm{s}^{-1}$
d). $\check{\mathrm{D}}_{\gamma}=4.61 \times 10^{-3} \mathrm{~Sv} \cdot \mathrm{s}^{-1}$
e). $\check{D}_{n}=3.74 \times 10^{-1} \mathrm{~Sv} \cdot \mathrm{s}^{-1}$

\section{Work Steps}

Research implementation procedures are formulated in a flow chart shown in Figure 2.

Algorithm research formulated in a flow chart shown in Figure 3.

\section{RESULTS AND DISCUSSION}

Component of In Vitro Irradiation Facility (3x2) holes

Component of in vitro irradiation facility (3x2) holes at Figure 4 . with a length of 12.8 $\mathrm{cm}$, height of $8.5 \mathrm{~cm}$ and a thickness of $2.5 \mathrm{~cm}$, has 3 holes in horizontal direction, and 2 holes in vertical direction with each hole diameter of $3.8 \mathrm{~cm}$. This component uses a plastic material (polystyrene) transparent. 


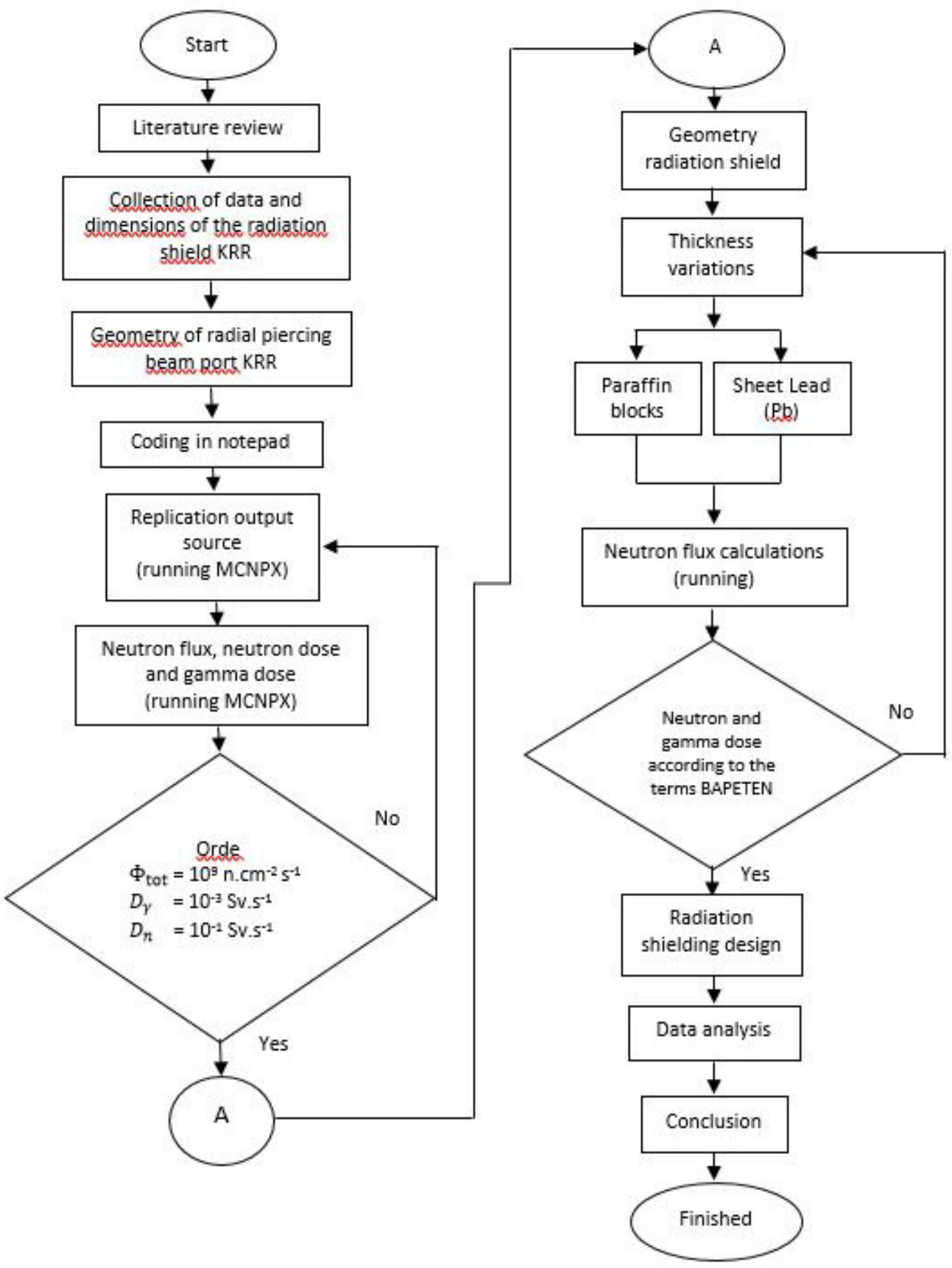

Figure 2. Research flow chart

\section{Component of In Vitro Irradiation Facility (6x4) holes}

Component of in vitro irradiation facility (6x4) holes at Figure 5. with length of $12.8 \mathrm{~cm}$, height of $8.5 \mathrm{~cm}$ and a thickness of $2.5 \mathrm{~cm}$, has a 6 hole in horizontal direction, and 4 holes in vertical direction with each hole diameter of $1.55 \mathrm{~cm}$. This component uses a plastic material (polystyrene) transparent.

\section{Component of Neutron Radiation Shielding}

Component of neutron radiation shielding in Figure 6.shaped beam with a length of $60 \mathrm{~cm}$, height $30 \mathrm{~cm}$ and a thickness of 15 $\mathrm{cm}$, use of paraffin (wax) with the following specifications:

- The bulk density was 0.93 g.cm .

- The composition of elements of $\mathrm{H}$ is $14.9 \%$. 


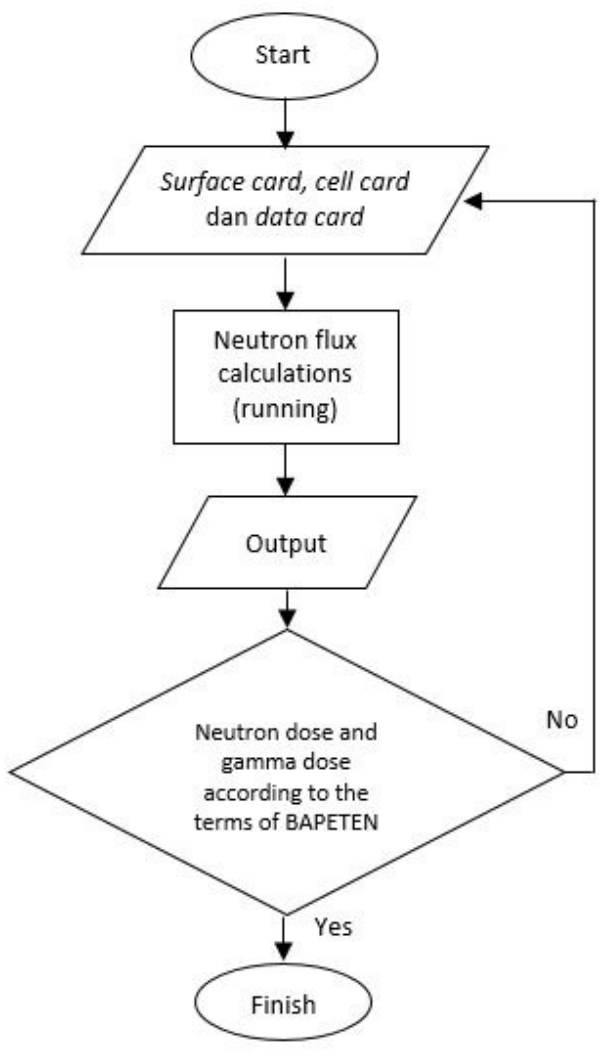

Figure 3. Algorithm research flow chart

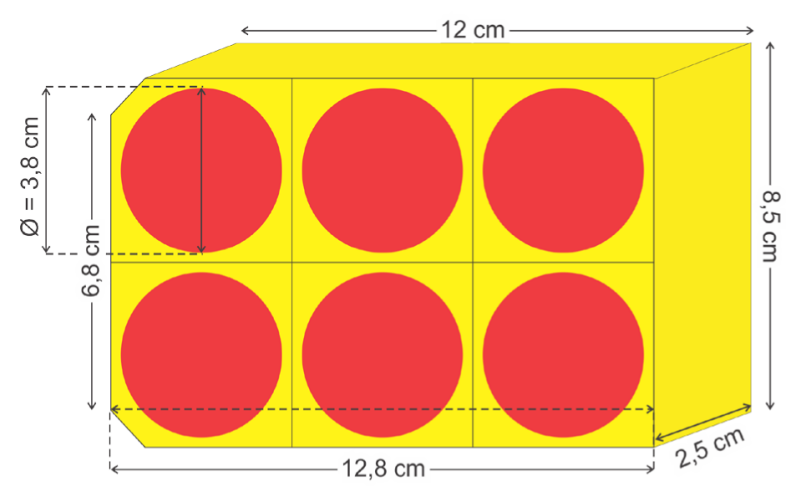

Figure 4. Component of in vitro irradiation facilitity $(3 \times 2)$ holes

- The composition of elements of $\mathrm{C}$ is $85.1 \%$.

\section{Component of Gamma Radiation Shielding}

Component of gamma radiation shielding in Figure 7.flat cuboid with a length of $50 \mathrm{~cm}$, height $50 \mathrm{~cm}$ and a thickness of $0.5 \mathrm{~cm}$, using materials of lead (lead) with mass density is 11.35 g.cm ${ }^{-3}$.

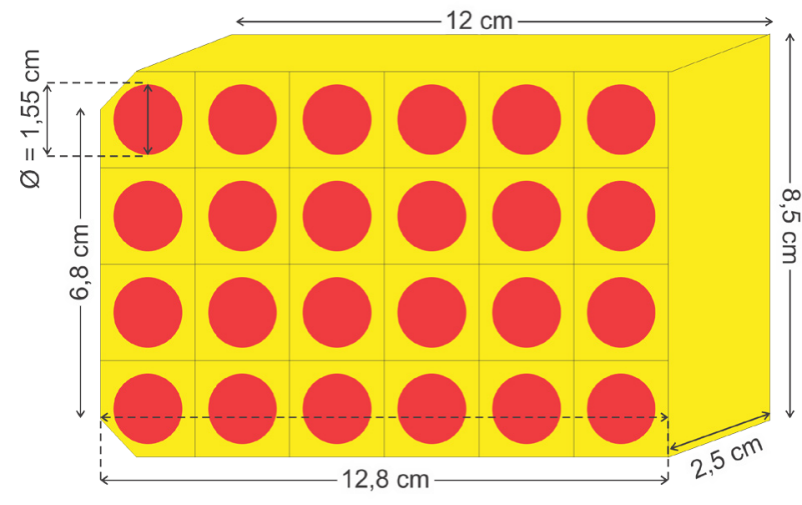

Figure 5. Component of in vitro irradiation facility $(6 \times 4)$ holes

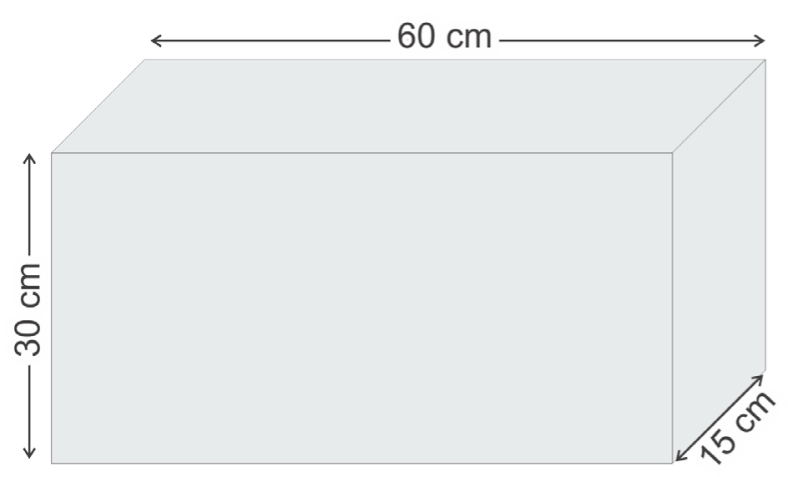

Figure 6. Component of neutron radiation shielding

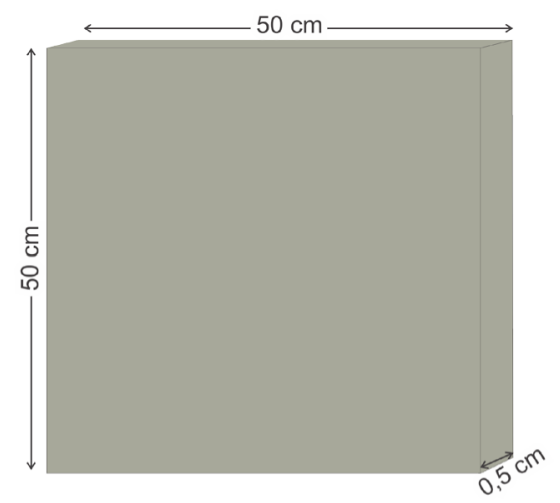

Figure 7.Component of gamma radiation shielding

Results of calculation using the simulation MCNPX for epithermal neutron flux in vitro test facility was $1.23 \times 10^{9} \mathrm{n} . \mathrm{cm}^{-2} \mathrm{~s}^{-1}$ same with the results of Dwi Wahyuningsih (2014) research at radial piercing beam port. Value of thermal neutron flux at in vitro test facility is greater than the results Dwi Wahyuningsih (2014), and for fast neutron flux is still in the same order as that $10^{9} \mathrm{n} \cdot \mathrm{cm}^{-2} \mathrm{~s}^{-1}$. This difference is 
due to the research Dwi Wahyuningsih (2014) only needs epithermal neutrons, so the thermal neutron component moderated by the neutron moderator material.

In the calculation of neutron and gamma doses, to obtain the output value in accordance with the results of previous studies used the multiplication factor of $1.46 \times 10^{6} \mathrm{n} \cdot \mathrm{Sv} \cdot \mathrm{s}^{-2}$. This is done by converting the unit of neutron flux into unit dose. Neutron and gamma dose calculation results in the in vitro test facility still one order with the results Dwi Wahyuningsih (2014).

\section{Irradiation Simulation}

Simulations needs irradiation for 6 hours, adapted to the operation of Reactor in one day. Radiation shielding design shown in Figure 8.a and 8.b.

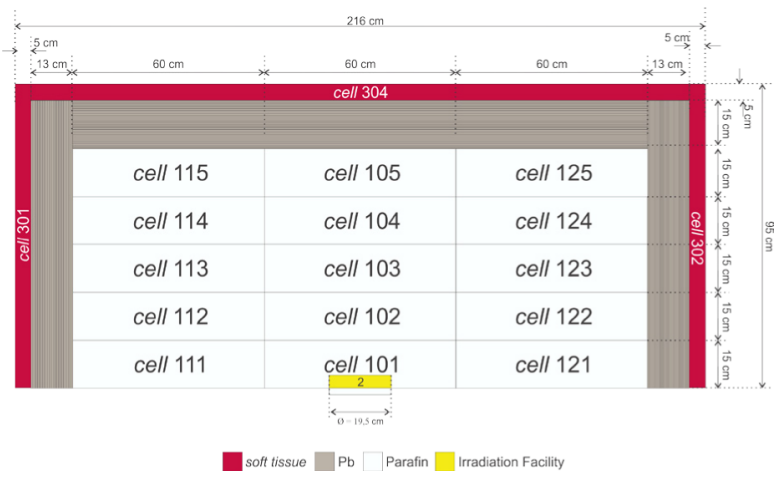

Figure 8a. Radiation Shielding Design for In Vitro Test Facility of BNCT methode at Radial Piercing Beam Port of Kartini Research Reactor Top View.

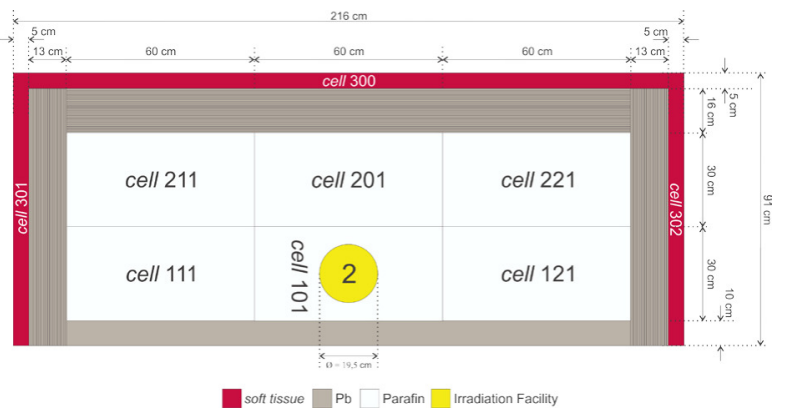

Figure 8b. Radiation Shielding Design for In Vitro Test of BNCT methode At Radial Piercing Beam Port Kartini Research Reactor Front View.
Radiation shield design in vitro BNCT facility at the port beam penetrating form of Reactor radial arrangement paraffin blocks and lead $(\mathrm{Pb})$. Paraffin is used as a radiation shield for neutrons. The composition of the beam paraffin in front of the beam port consists of three pieces of beams are arranged as a basis (cell 111, cell 101, cell 121) and 3 pieces of beams are arranged on it (cell 211, cell 201, cell 221) is illustrated in Figure 8. b. Each beam has a 5 cell arranged behind which are illustrated in Fig 8.a. So the total number of paraffin blocks required is 30 pieces. One of the paraffin block containing irradiation facilities in vitro that the cell 101. Gamma shield arranged in the form of lead after a block of paraffin. There are 5 arrangements of leads which is located on the left side, right side, top side, bottom side and rear side. On the left and right sides of lead are arranged up to a thickness of $13 \mathrm{~cm}$. On the upper side are arranged up to a thickness of 16 $\mathrm{cm}$. On the back side until it reaches a thickness of $15 \mathrm{~cm}$. On the down side $10 \mathrm{~cm}$ because it does not affect directly with humans.

MCNPX running results of the design of the radiation dose rate that came out after passing through the radiation shield is presented in Table 1. These results are in accordance with the safety standards recommended by BAPETEN it is $20 \mathrm{mSv}_{\text {.year }}{ }^{-1}$, equivalent to $2.78 \mathrm{nSv} . \mathrm{s}^{-1}$.

Table 1. Simulation results of dose rate radiation which is detected in soft tissue.

\begin{tabular}{cccc}
\hline No cell & $\check{\mathrm{D}}_{\gamma}\left(\mathbf{S v . s}^{-\mathbf{1}}\right)$ & $\check{\mathrm{D}}_{\mathbf{n}} \mathbf{( S v . s - 1 )}$ & Explanation \\
\hline 300 & $1.79 \times 10^{-09}$ & $2.31 \times 10^{-10}$ & Top \\
301 & $2.46 \times 10^{-09}$ & 0 & Left \\
302 & $1.81 \times 10^{-09}$ & 0 & Right \\
304 & $1.39 \times 10^{-09}$ & $2.12 \times 10^{-10}$ & Back \\
\hline
\end{tabular}

\section{CONCLUSION AND REMARKS}

Based on the research that has been done, it can be concluded as follows. 
1. Output value of the radial piercing beam port of Kartini Research Reactor using the simulator MCNPX is as follows.

a. Thermal neutron flux is $5.00 \times 10^{8} \mathrm{n} . \mathrm{cm}^{-}$ ${ }^{2} \mathrm{~S}^{-1}$.

b. Epithermal neutron flux is $1.23 \times 10^{9}$ n.cm $\mathrm{cm}^{-2} \mathrm{~s}^{-1}$.

c. Fast neutron flux is $1.35 \times 10^{9} \mathrm{n} \cdot \mathrm{cm}^{-2} \mathrm{~s}^{-1}$.

d. Gamma dose rate is $2.49 \times 10^{-3} \mathrm{~Sv}_{\mathrm{s}}{ }^{-1}$.

e. Neutron dose rate is a $3.63 \times 10^{-1}$ Sv.s ${ }^{-1}$.

2. Design of irradiation facilities and biological shielding for BNCT in vitro test on radial piercing beam port of Kartini Research Reactor corresponding to the material provided in PSTA BATAN is as follows.

a. Components of irradiation facilities in vitro $(3 \times 2)$ holes.

Components of irradiation facilities in vitro $(3 \times 2)$ form beams with a length of $12.8 \mathrm{~cm}$, height $8.5 \mathrm{~cm}$ and $2.5 \mathrm{~cm}$ thick. Contains 6 holes and each have a diameter of $3.8 \mathrm{~cm}$.

b. Components of irradiation facilities in vitro $(6 \times 4)$ holes.

Components of irradiation facilities in vitro $6 \times 4$ holesform beams with a length of $12.8 \mathrm{~cm}$, height $8.5 \mathrm{~cm}$ and $2.5 \mathrm{~cm}$ thick. Containing 24 holes and each have a diameter of $1.55 \mathrm{~cm}$.

c. Components of biological shielding radiation.

Radiation shielding design for in vitro test BNCT on radial piercing beam port of Kartini Research Reactor according to the material available in the PSTA BATAN is an array of paraffin blocks and lead $(\mathrm{Pb})$. Paraffin is used as a radiation shield for neutrons. The composition of the paraffin blocks in front of the port beam consists of three pieces of beams are arranged as a basis (cell 111, cell 101, cell 121) and 3 pieces of beams are arranged on it (cell 211, cell 201, cell 221). Each beam has a 5 cell arranged behind. So the total number of paraffin blocks required is 30 pieces. One of the paraffin block containing irradiation facilities in vitro that the cell 101. Gamma shield arranged in the form of lead after blocks of paraffin. There is 5 arrangement of leads which is located on the left side, right side, top side, bottom side and rear side. On the left and right sides of lead are arranged up to a thickness of $13 \mathrm{~cm}$. On the upper side are arranged up to a thickness of 16 $\mathrm{cm}$. On the back side until it reaches a thickness of $15 \mathrm{~cm}$. On the down side $10 \mathrm{~cm}$ enough because it does not deal directly with humans.

3. The output of biological shielding is as follows.

Output value after a radiation shield in accordance with the provisions BAPETEN in Perka $4 / 2013$ is below the $2.78 \times 10^{-9} \mathrm{~Sv}^{-1}{ }^{-1}$ shown as follows.

a. Cell No. 300 with $\mathrm{D}_{\gamma}$ is $1.79 \times 10^{-09} \mathrm{~Sv}^{-1} \mathrm{~S}_{\mathrm{n}}$ is $2.31 \times 10^{-10} \mathrm{~Sv} . \mathrm{s}^{-1}$ on the upper side.

b. Cell No. 301 with $\mathrm{D}_{\gamma}$ is $2.46 \times 10^{-09} \mathrm{~Sv}^{-1} \mathrm{~s}^{-1}$, $\mathrm{D}_{\mathrm{n}}$ is $0 \mathrm{~Sv} \cdot \mathrm{s}^{-1}$ on the left side.

c. Cell No. 302 with $\mathrm{D}_{\gamma}$ is $1.81 \times 10^{-09} \mathrm{~Sv}^{-1}{ }^{-1}$, $D_{n}$ is $0 \mathrm{~Sv}^{-1}{ }^{-1}$ on the right side.

d. Cell No. 304 with $\mathrm{D}_{\gamma}$ is $1.39 \times 10^{-09} \mathrm{~Sv}^{-1}, \mathrm{D}_{\mathrm{n}}$ is $2.12 \times 10^{-10} \mathrm{~Sv} \cdot \mathrm{s}^{-1}$ on the back side.

\section{ACKNOWLEDGMENT}

This research was supported by Center for Science and Accelerator Technology (PSTA) BATAN Yogyakarta. We thank to my supervisor Mr. Widarto upon guidance. Prof. Yohannes Sardjono as a chairman of the consortium. Supervisors of Kartini Research Reactor on occasion for me to learn more about Kartini Research Reactor. Our colleagues from Gadjah Mada University (Ilma,S.T, Bambang, S.T and Dwi, M.Si) for assistance with particular 
technique and methodology, and Indry, S.Si. from Yogyakarta State University for being partner in this research and all colleagues who have given support and aspirations, especially to BNCT Researchers Indonesia.

\section{REFERENCES}

Bambang Hadi S. (2014). Pemodelan Perisai Radiasi Fasilitas Bnct Dengan Sumber Beamport Tembus Teras Reaktor Kartini Menggunakan MCNP5. Skripsi. Yogyakarta: Universitas Gadjah Mada.

BAPETEN.(2013). Peraturan Kepala Badan Pengawas Tenaga Nuklir (BAPETEN) Nomor 4 Tahun 2013 Tentang Proteksi Dan Keselamatan Radiasi Dalam Pemanfaatan Tenaga Nuklir. Jakarta.

BATAN.(2013). Reaktor Kartini. Yogyakarta: PTAPB BATAN.

BATAN. (2014). Standar Operasional Prosedur (SOP): Eksperimen Analisis Dan Kerakteristik Fluks Neutron Pada Beamport Tembus Radial Untuk Fasilitas Dan Kajian Pendayagunaan Reaktor Kartini. Nomor Dokumen: SOP 073.2/RN0001/STA 4. Yogyakarta: PSTA BATAN.

Denise B. Pelowitz. (2008). MCNPXTM User's Manual Version 2.6.0. Los Alamos, New Mexico: Los Alamos National Laboratory. Dwi Wahyuningsih. (2014). Optimasi Desain Kolimator untuk Uji In Vivo Boron Neutron Capture Therapy (BNCT) pada Beamport Tembus Reaktor Kartini Menggunakan Simulasi Monte Carlo N Particle 5 (MCNP5). Tesis. Yogyakarta: Universitas Gadjah Mada.
Ilma Muslih A, M. (2013).Perancangan Kolimator di Beam Port Tembus Reaktor Kartini Untuk Boron Neutron Capture Therapy (BNCT).Skripsi. Yogyakarta: Universitas Gadjah Mada.

Indry Septyana Novitasari. (2015). Analisis Fluks Neutron pada Beamport Tembus Radial Reaktor Kartini untuk Fasilitas Uji In Vivo dan In Vitro Boron Neutron Capture Therapy (BNCT). Skripsi. Yogyakarta: Universitas Negeri Yogyakarta.

Kemenkes RI. (2013a). Profil Kesehatan Indonesia 2012. Jakarta.

Kemenkes RI. (2013b). Riset Kesehatan Dasar (Riskesdas) 2013. Jakarta.

Kemenkes RI. (2014). Profil Kesehatan Indonesia Tahun 2013. Jakarta.

Nina Fauziah. (2013). A Conceptual Design of Neutron Collimator in the Thermal Column of Kartini Research Reactor for Boron Neutron Capture Therapy.Skripsi. Yogyakarta: Universitas Gadjah Mada.

Sauerwein, Wolfgang A.G. dan Moss, Ray L. (2009).Requirement for Boron Neutron Capture Therapy (BNCT) at a Nuclear Research Reactor.The European BNCT Project. Belanda: European Communities. Schwarz, A.L., R.A. Schwarz, dan L.L. Carter (2008). MCNP/MCNPX Visual Editor Computer Code Manual.Diakses dari http:// www.mcnpvised.com, 21 Januari 2015.

WHO. (2012). Noncommunicable Diseases: A Major Health Challenge of the 21st Century. World Health Statistic 2012. Hlm. 34-45. Jenewa: WHO Press 